\title{
Examining the Effect of Strategy Instruction on Writing Apprehension and Writing Achievement of EFL Learners
}

\author{
Fatemeh Mohseniasl \\ Department of English Language Teaching, Science and Research Branch, Islamic Azad University Tehran, Iran
}

\begin{abstract}
Writing as a communicative activity imposes great difficulties on EFL learners and both cognitive and affective aspects of writing have a sharing part in this complex process. The current study aimed to explore the effect of explicit writing strategy instruction, prewriting strategies in particular on reducing writing apprehension, and promoting writing performance.42 intermediate EFL students participated in this study, 28 students in two experimental groups received the treatment and the results compared to their 14 counterparts in the control group. All the participants received Writing Apprehension Test (WAT) as the pretest and posttest. They further were expected to write two expository essays at the beginning and end of the study. After administrating the pretests and posttests, the results reflected on the effectiveness of explicit writing strategy instruction and the potentials of prewriting strategies in alleviating the level of writing apprehension. Further, explicit instruction of prewriting strategies greatly optimized the writing achievement of students in the two experimental groups. The findings of the present study also suggest that the implementation of explicit strategy instruction by the teacher can make a world of difference for students in learning process.
\end{abstract}

Index Terms — explicit strategy instruction, prewriting stage, writing apprehension

\section{INTRODUCTION}

Apprehension as one of the prominent affective factors has stimulated particular attention in second and foreign language acquisition and learning. One of the major reasons for this concern particularly among researchers and educators is its potential negative effects (Atay \& Kurt, 2006; Ehram \& Oxford, 1995; MacIntyer, et al., 1997). Moreover, English as a Foreign Language (EFL) setting like the other educational settings is experiencing the problem of anxiety in foreign language in different domains of language (Ozturk \& Cecen, 2007). In this respect, Tsui (1996) believes that learning to write in a foreign language involves as much anxiety as learning the other skills. Since writing is predominantly product-oriented, it requires individual work that is students are deprived of help, support and encouragement. As the result, learners suffer a distress and anxiety associated with the writing process. More importantly, considering writing as cornerstone of language learning skill, many studies pinpoint the importance of writing anxiety as a specific type of anxiety, unique to the language particular skill of writing (Bline, et al., 2001; Cheng, et al., 1999; Daly \& Wilson, 1983). Only recently, writing apprehension due to its sensitivity to EFL contexts (Masny \& Foxall, 1992) calls the researchers' attention to this phenomenon and its specific relation to the language learning. Despite the plethora of studies on writing apprehension in the first language (Atkinson, 2011; Boeing, Anderson \& Miller, 1997; Clark, 2004; Daly, 1978; Daly \& Miller, 1975; Faigley, Daly \& Witte, 1981; Fox, 1980; Marshall \& Varnon, 2009; Rankin-Brown, 2006 Reeves, 1997; Teichman \& Poris, 1989), a new trend has been taken toward the study of writing apprehension in EFL context. A number of studies pinpoint the importance of investigating writing apprehension in this context (Atay \& Curt 2007; Cheng, 2004; Cheng, et al., 1999; Erkan \& Saban, 2010; Hassan, 2001; Lee, 2005; Ozturk \& Cecen, 2007; Salem, 2007; Song, 1998). It should be noted that writing anxiety and writing apprehension are usually used interchangeably; however, writing apprehension has gained popularity in more recent research in literature (Cheng, et al., 1999).

The study of writing apprehension began as a subset of research on communication apprehension. Daly and Miller (1975) coined the term writing apprehension in order to describe the tendency of a person to avoid the process of writing particularly when it is evaluated in some way (Erkan \& Saban, 2010). Apprehensive students are likely to suffer from the concern about the possibility of failure, flawed performance, fear of evaluation, negative attitudes toward writing task and writing situation (Cheng, et al., 1999, Daly, 1978; Huwari \& Aziz, 2011), their writing performance are mostly lifeless, mechanical, full of grammatical errors, repeated concepts and unsupported organization ( Hettich, 1994).

As there is a widespread consensus among the researchers to propose the role of classroom strategies and explicit instruction on various stages of writing process (Charney, et al.,1995; Huwari \& Aziz, 2011; Oxford,2002; Marshall \& Varon, 2009; Masny \& Foxall, 1992; Wu, 2010) specifically prewriting stage as the most crucial stage in order to mitigate the problems associated with these phenomena, the current study focused on explicit writing strategies instruction which its effectiveness on the learners' writing performance has been highlighted by many studies ( Chamot, 
2005; Cohen, 1996; Negari, 2011). Chamot, et al., (1990) assert that the purpose of the writing strategy instruction is to make students aware of writing process and to teach them the strategies associated with the good writing. Moreover, Chamot (2004) maintains that explicit strategy instruction essentially involves the development of students' awareness of the strategies they use and teacher modeling of strategic thinking. Further, student practice with new strategies, student self-evaluation of strategies used and practice in transferring strategies to new tasks are involved as well. More specifically, this study emphasizes on prewriting stage since most of the students' writing problems that teachers have control on them stem from insufficient preparation for their writing assignments (Chastain, 1988). Seow (2002) defines pre writing as "any activity in the classroom that encourages students to write. It stimulates thoughts for getting started (p, 316)". Due to the necessity of exposing students to a variety of strategies to initiate the writing task and to encourage students to practice all the strategies and discover the one that serves them best (Kroll, 2001), three prewriting strategies namely brainstorming, concept mapping and free writing have been chosen in tandem all with the aim of generating and organizing ideas which open the mind of students and are effective at the moment of blocking and confusion. Regarding the issue of explicit writing strategy instruction and the prewriting stage as the foundation of good writing which has received only minor attention in EFL contexts (Schweiker-Marra \& Marra, 2000; Stern, 1991) further, the fact that writing environment is conductive to exploring ideas and content ( Masny \& Foxall, 1992) and the terror of the blank page which may be faced by so many students ( Kroll, 2001), more research appears to be needed investigating writing apprehension the role of instructional strategies in alleviating the negative consequences of this two phenomenon.

\section{METHOD}

\section{A. Participants}

The participants in this study were 57 intermediate EFL learners, 16 males and 41 females in three classes in a language institute in Iran. Their age ranged from 16 to 30 with the average age of 20 . To ensure their homogeneity in terms of language proficiency, TOEFL was conducted in the three classes. The results indicated that there was not any significant difference among the performance of the three groups. The participating students were all native speakers of Persian. All of whom had been learning English for more than five years. At the end of the course, 15 students were excluded from the study as they did not participate in the posttest. So, the number of the participants decreased to 42 students. There were 14 students in each of the three groups. Two groups randomly were selected as the experimental groups and the third group was considered as the control group.

\section{B. Instruments}

For the purpose of this study, a number of instruments were used. In order to measure the degree to which an individual feels apprehensive when writes in English, the Writing Apprehension Test (WAT) developed by Daly and Miller (1975) was used (see Appendix A). This test has been extensively used in writing researches and proven to be reliable and valid to be used in both ESL and EFL contexts with the reported Cronbach alpha above .90 (Daly \& Miller, 1975; Lee \& Krashen,2003; Lee, 2001; Lee, 2005). It consists of 26 statements, 13 positive statements and 13 negative statements which are answered on a five-point Likert scale ranging from "strongly agree" to "strongly disagree". Further, a "strongly agree" response to a negative question is scored as 5 and a "strongly agree" response to a positive statement is scored as 1 . The scores may range from a low of 26 to a high of 130. High scores indicate high levels of apprehension. In additions, two writing topics were selected for pretest and posttest (see Appendix B) and students were offered to write two expository essays about 250 words for about forty minutes. Considering the writing performance, each writing paper was rated based on Jacobs et al. (1981, as cited in Weigle, 2002). According to Jacob et al. scale, five aspects of writing are considered in scaling each writing paper: content, organization, vocabulary, language use and mechanics. Moreover, a handout which included definitions of prewriting strategies, namely brainstorming, concept mapping and free writing with the different examples of them was given to the students in the two experimental groups who received the explicit writing strategy instruction as a treatment.

\section{PROCEDURE}

The instructional period lasted about twelve sessions for about one hour and thirty minutes each session and comprised of three phases. Homogeneity of the students in terms of language proficiency was established through TOEFL. The results indicated that there was not any significant difference between the performance of the two experimental groups and the control group.

\section{A. Phase One}

Prior to the instruction, at the first session, two experimental and one control groups received Writing Apprehension Questionnaire (WAT) as the pretest. Further, they wrote about a selected topic about forty minutes.

\section{B. Phase Two}

After all the students participated in the pretest, during the next ten sessions, the two experimental groups received a handout that included definitions of prewriting strategies, namely brainstorming, concept mapping and free writing. The 
presentation of these strategies was in consecutive manner. Explicit teaching of writing strategy was presented to the two experimental groups following Chamot et al., guideline (1990):

1. Presenting the name and description of strategy: The teacher first capitalizing on what students already know about writing in English gave an overview of strategies before actually beginning the instruction. Then the teacher presented all the description and required information for the strategies as well as the purposes, the benefits and the significance of each one.

2. Modeling the strategy: The teacher presented the examples of each writing strategies on the board and modeled them for the students. Moreover, the teacher modeled how to rewrite the gathered information into complete sentences.

3. Make practice of strategies: During each session, the students practiced on the provided topics and rehearsed the use of each strategy

4. Guide and feedback: during the sessions, needed guide and feedback provided for the students.

For the first presentation of each strategy, the instructor let students think individually for five minutes get ready for the writing, tap their imagination for information and fresh their minds and ideas. For the first practice, the students were allowed to practice the use of strategy on the board and in their notes under the supervision of the instructor. They further were allowed to verbalize their ideas in pairs or groups in order to exchange their ideas and collaborate with each other. Moreover, brainstorming and concept mapping were taught in tandem. When the students finished brainstorming about one topic "role of fast food in today life" for example, there may be a variety of ideas about it. The instructor asked the students to gather all the key terms and those phrases related to "health effect" in one category and paved the way to teach concept mapping and how to organize the ideas in the graphical representation. In addition, the students rehearsed free writing on several topics as a daily practice. The instructor taught the students to use connectors to organize the key terms and phrases into sentences to write a paragraph. Many writing practices were provided for the students in order to be able to use strategies individually and in their notes as well.

The instruction for the control group conducted in the conventional form that is the flow of the course was similar to the regular writing course. The class followed the routines without receiving any instruction of strategy use in writing. The same instructor taught the students in the control group with the same hours of instruction.

\section{Phase Three}

At the last session, the three groups received the Writing Apprehension Questionnaire (WAQ) as the posttest and they wrote about a selected topic. The allotted time for writing was forty minutes.

Considering their writing performance, their writing papers were scored based on Jacob et al. (1981, as cited in Weigle, 2002) by two raters. The interrater reliability for pretest and posttest were .952 and .963 respectively. According to Jacobs et al., scaling each paper was rated one five aspects of writing: content, organization, vocabulary, language use and mechanics. These five aspects are weighted to emphasize first content (30 points), language use (25 points), organization and vocabulary equally (20 points) and mechanics with very little emphasis (5 points). The final score for each paper was the average score of the two scores given by the two independent raters.

\section{RESULTS AND DisCUSSIONS}

\section{A. Test of Homogeneity of the Groups}

The results of one- way ANOVA indicated that there was not any significant difference between the performance of the two experimental and the control groups $\mathrm{F}(2,39)=.117, p=.890, p<0.05$.

TABLE 1 .

ONE-WAY ANOVA TEST OF HOMOGENEITY FOR THE THREE GROUPS IN TOEFL

\begin{tabular}{llllll}
\hline \multicolumn{2}{l}{ ANOVA TOEFL Grades } & & & & \\
\hline & Sum of Squares & df & Mean Square & F & Sig. \\
Between Groups & 4.619 & 2 & 2.310 & .117 & .890 \\
Within Groups & 772.357 & 39 & 19.804 & & \\
Total & 776.976 & 41 & & & \\
\hline
\end{tabular}

\section{B. Results on Writing Apprehension Test}

This study examines whether there is a significant difference between those students who received explicit instruction of prewriting strategies in the experimental groups and the other students in the control group. Considering pretests' mean scores in Table 2, the mean score of the first experimental group showed that the participants experienced high level of writing apprehension. The second experimental group had lower writing apprehension and the participants in the control group had a moderate level of writing apprehension before administrating the treatment. After the data were collected through writing apprehension test as posttest, three Paired Sample t-tests were conducted in order to examine the effectiveness of the treatment and whether each group's writing apprehension changed after the treatment (Table 2). considering the mean scores and the level of significance $(p<0.05)$, there is a statistically significant decrease in the mean scores of the first experimental group from the pretest $(M=81.2143)$ to the posttest $(M$ $=74.4286), p=.001, t(13)=4.552$. Therefore, it can be concluded that explicit writing strategy instruction has a positive effect on the first experimental group and there is a statistically significant improvement in terms of writing 
apprehension. Furthermore, there is an insignificant decrease in the mean scores of the second experimental group from the pretest $(M=74.4286)$ to the posttest $(M=71.7143), p=308, p=<0.05, t(13)=1.061$. Though there is a decrease in the mean scores of this group from the pretest to posttest, the level of significance does not demonstrate statistically significant improvement. On the other hand, there is a statistically significant decrease in the mean scores of the control group from the pretest $(M=78.8571)$ to the posttest $(M=76.5714), p=.014, p<0.05, t(13)=2.853$. Therefore, there is a statistically significant improvement in terms of writing apprehension which is likely due to the chance. These findings are in line with the findings of Fox (1980), Holmes and Moulton (2003), Salem (2007) and Wu (2010) who adopted process approach to writing instruction and relieved the levels of apprehension by providing a non-threatening environment in the classrooms.

TABLE 2.

PAIRED-SAMPLE T-TESTS OF WAT FOR EACH OF THREE GROUPS

\begin{tabular}{|c|c|c|c|c|c|c|c|}
\hline \multicolumn{8}{|c|}{ Paired differences } \\
\hline & & Mean & $\underline{S D}$ & Std. Error Mean & $\underline{\mathrm{t}}$ & Df & $\underline{\text { Sig.(2-tailed) }}$ \\
\hline Pair 1 & Pretest & 81.2143 & 7.60747 & 2.03318 & 4.552 & $\underline{13}$ & .001 \\
\hline Ex G1 & Posttest & 74.4286 & 5.94480 & 1.58881 & & & \\
\hline$\overline{\text { Pair } 1}$ & Pretest & 74.4286 & 7.26122 & 1.94064 & $\underline{1.061}$ & $\underline{13}$ & .308 \\
\hline$\underline{\mathrm{Ex} \mathrm{G} 2}$ & Posttest & $\overline{71.7143}$ & 6.70738 & $\overline{1.79262}$ & & & \\
\hline$\overline{\text { Pair } 1}$ & Pretest & $\overline{78.8571}$ & $\underline{3.73872}$ & .99921 & 2.853 & $\underline{13}$ & .014 \\
\hline$\underline{\mathrm{C} \mathrm{G}}$ & Posttest & $\underline{76.5714}$ & 5.01865 & 1.34129 & & & \\
\hline
\end{tabular}

\section{Results of Writing Achievements}

The second issue addressed in this study was whether the explicit instruction of prewriting strategies would improve students' writing achievement in the two experimental groups. Conduction of one-way ANOVA (Table 3) showed that there was not any significant difference between three groups in terms of writing performance $F(2,39)=1.286, p$ $=.288, p<0.05$. Therefore, all the participants in the two experimental groups and the one control group had the same writing performance prior instruction.

TABLE 3.

TEST OF BETWEEN GROUPS ON PRETESTS OF WRITING PERFORMANCE

\begin{tabular}{llllll}
\hline ANOVA Pre & \multicolumn{3}{c}{} \\
\hline & Sum of Squares & df & Mean Square & F & Sig. \\
Between Groups & 238.536 & 2 & 119.268 & 1.286 & .288 \\
Within Groups & 3617.875 & 39 & 92.766 & & \\
Total & 3856.411 & 41 & & & \\
\hline
\end{tabular}

After students' participation in the posttest of writing performance, three separate Paired Sample t-tests were run to examine each group's writing achievement separately (Table 4). Considering the mean scores and the level of significance $(p<0.05)$, there was a statistically significant increase in the mean scores of the first experimental group from pretest $(M=68.7143)$ to the posttest $(M=81.9286), p=.000, p<0.05, t(13)=-5.317$. Furthermore, there was a statistically significant increase in the mean scores of the second experimental group from pretest $(M=62.8929)$ to the posttest $(M=75.8214), \quad p=.000, p<0.05, t(13)=-8.076$. On the other hand, there was not any statistically significant difference in the mean scores of the control group from the pretest $(M=65.4286)$ to the posttest $(M=66.4286), p$ $=.615, p<0.05, t(13)=-.516$. Therefore, the two experimental groups outperformed in the posttest writing in comparison to the control group. In other words, the learners' performances in the control group were lower than the two experimental groups and there was not any statistically significant difference between the pretest and posttest of the control group $(p=.615, p<0.05)$. The findings of this fraction of study are consistent with the findings of Ahangari \& Behzadi (2012), Chularut \& DeBacker (2004), Dujsik (2008), Goldstein \& Carr (1996), Ibnian (2011), Li (2007), Negari (2011), Ojima (2006), Piovesan (2007), Pishghadam \& Ghanizadeh (2006), Roa (2007) and Talebinezhad \& Negari (2007) who tried to provide evidence for the effectiveness of brainstorming, concept mapping and free writing as a prewriting strategies.

TABLE 4.

PAIRED-SAMPLE T-TESTS OF WRITING PERFORMANCE FOR EACH OF THREE GROUPS

\begin{tabular}{|c|c|c|c|c|c|c|c|}
\hline \multicolumn{8}{|c|}{ Paired differences } \\
\hline & & Mean & $\underline{\mathrm{SD}}$ & $\underline{\text { Std. Error Mean }}$ & $\underline{\mathrm{t}}$ & $\underline{\mathrm{df}}$ & Sig.(2-tailed) \\
\hline Pair 1 & $\underline{\text { Pretest }}$ & $\overline{68.7143}$ & $\underline{12.28776}$ & 3.28404 & -5.317 & $\underline{13}$ & .000 \\
\hline$\overline{\text { Ex G1 }}$ & Posttest & 81.9286 & 10.04194 & 2.68382 & & & \\
\hline$\overline{\text { Pair 1 }}$ & $\overline{\text { Pretest }}$ & 62.8929 & 8.13865 & 2.17515 & $\underline{-8.076}$ & $\underline{13}$ & .000 \\
\hline$\overline{\mathrm{Ex} \mathrm{G} 2}$ & Posttest & 75.8214 & $\overline{5.77663}$ & 1.54387 & & & \\
\hline$\overline{\text { Pair 1 }}$ & Pretest & $\overline{65.4286}$ & 7.81482 & 2.08860 &.- .516 & $\underline{13}$ & .615 \\
\hline $\mathrm{CG}$ & Posttest & 66.4286 & 7.81482 & 2.42177 & & & \\
\hline
\end{tabular}




\section{CONCLUSION ANd PEDAgOgicAl IMPLiCATIONS}

This study reflected on the effectiveness of explicit writing strategy instruction and the potentials of prewriting strategies in provoking the dormant thought. It shed lights on both cognitive and affective aspects of writing skill which play indispensable role in the complex process of writing. It proved the effectiveness of equipping students with the efficient composing process which resulted in positive outcomes. Furthermore, the current study supported the Chen's statement (2007) that the impact of explicit instruction engages learners more to the dynamic internal changes in the learning process as the learners became more sensitive to the learning process and were willing to know about other stages of writing process by the end of the course.

This study has some implications for language teaching and learning pertaining to the problems of apprehension, blocking and composing. The fact that writing in a foreign language imposes great difficulties on EFL learners and both cognitive and affective aspects of writing have a sharing part in it, writing instruction should be conducted in a way to be most beneficial for foreign language learners. Cohen and Macaro (2007) assert that "the ultimate goal of any language instruction is not only to teach learners for a moment but to instill within learners a sense of what it is like to be a lifelong language learner"(p.284). Furthermore, the implementation of strategy instruction in language classrooms provides true guidance and ample opportunity for learners to practice more. Therefore, language classrooms should have a dual focus on both teaching content and learning strategies.

Prewriting strategies can be considered as a fruitful platform for students to generate as many ideas as possible and crystalize their dormant thought to embark on the complex process of writing. Further, students are able to overcome the problems of losing the track of mind, prepare a fair plan in order to refer to it in other stages of writing process. Its consideration by the teachers and educational designers can help students to reinforce their confidence, creativity and their performance and help students to enjoy the process of writing.

\section{APPENDIX A. WRITING APPREHENSION QUESTIONNAIRE}

Directions: below are 26 statements about writing. Please mark from "Strongly disagree" to "strongly agree" that best describe your agreement or disagreement with these statements. Remember that there are no correct answers; only give your honest response.

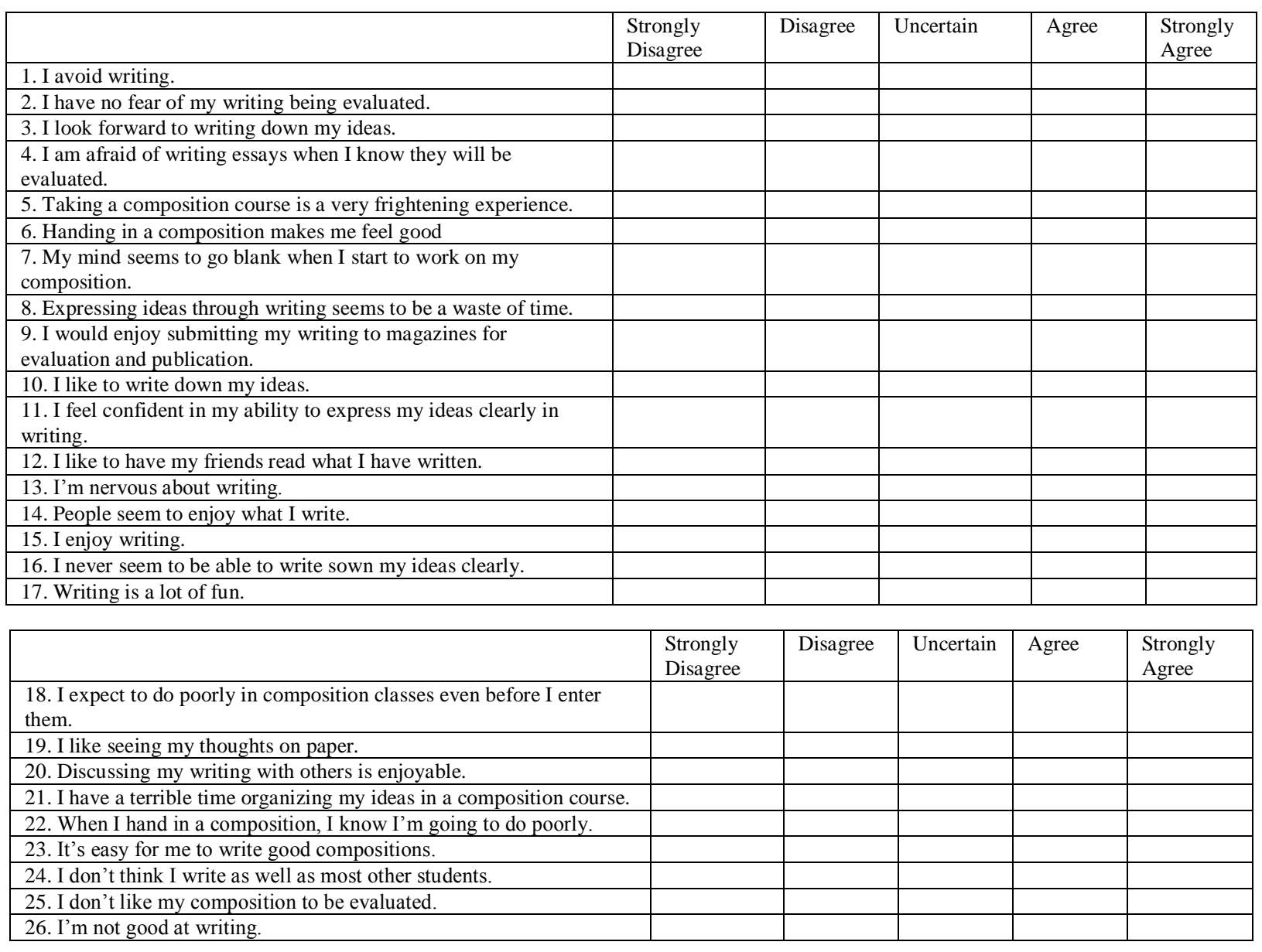




\section{Pretest}

\section{A: Please write about 250 words on the following statement:}

Some people believe that students should be required to attend classes. Others believe that going to the classes should be optional for students. Which point of view do you agree with? Use specific reasons and details to explain your answer.

\section{Posttest}

\section{B: Please write about 250 words on the following statement:}

Do you agree or disagree with the following statement? With the help of technology, students nowadays can learn more information and learn it more quickly. Use specific reason and example to support your answer.

\section{REFERENCES}

[1] Ahangari, S., \& Behzady, L. (2012). The effect of explicit teaching of concept maps on Iranian EFL learners' writing performance. American Journal of Scientific Research, 61,100-112.

[2] Atay, D., \& Kurt, G. (2006). Prospective teachers and L2 writing anxiety. Asian EFL Journal, 8(4), 100-118.

[3] Atkinson, P.B. (2011). Exploring correlation between writing apprehension, academic rational beliefs, stress and coping behaviors in college students. Proceeding of the New York State Communication Association,2010,1.

[4] Bline, D., Lowe, D.R., Meixner, W.F., Nouri, H., \& Pearce, K. (2001). A research note on the dimensionality of Daly and Miller's writing apprehension scale. Written Communication, 18, 61-79.

[5] Boening, C. H., Anderson, L. A., \& Miller, M. T. (1997).Writing apprehension and academic achievement among undergraduate honors students. Retrieved October 2012 from http://www. eric.ed.gov.

[6] Chamot, A. U. (2004). Issues in language learning strategy research and teaching. Electronic Journal of Foreign Language and Teaching1, (1), 14-26. Retrieved November 2012 From http://www.e-flt.nus.edu.sg.

[7] Chamot, A.U. (2005). Language learning strategy instruction: Current issues and research. Annual Review of Applied Linguistics, 25, 112-130.

[8] Chamot, A.U., Toth, S., Kupper, L., Nielsen, R., \& Barrueta, M. (1990).Learning Strategy instruction in the foreign language classroom: Writing. Retrieved November 2012 from http://www.eric.ed.gov.

[9] Charney, D., Newman, J.H., \& Palmquist, M. (1995). I'm just no good at writing: Epistemological style and attitudes toward writing. Written Communication, 12, 298-329.

[10] Chastain, K. (1988).Writing. Developing second language skills (pp.244-264). United State of America: Harcourt Brace.

[11] Chen, Y. (2007). Learning to learn: the impact of strategy training. ELT Journal, 61(1). doi:10.1093/elt/ccl041. http://dx.doi.org/10.1093/elt/ccl041.

[12] Cheng, Y.-S. (2004).A measure of second language writing anxiety: Scale development and preliminary validation. Journal of Second Language Writing, 13,313-335.

[13] Cheng, Y.-S., Horwitz, E.K., \&Schallert, D. (1999). Language anxiety: Differentiating writing and speaking components. Language Learning, 49, 417-446.

[14] Chularut, P., \& DeBacker, T. K. (2004). The influence of concept mapping on achievement, self-regulation and self-efficacy in students of English as a second language. Contemporary Educational Psychology, 29, $248-263$. doi:10.1016/j.cedpsych.2003.09.001. http://dx.doi.org/10.1016/j.cedpsych.2003.09.001.

[15] Clark, D. C. (2004).Exploration into writing anxiety: Helping students overcome their fears and focus on learning. Retrieved October 2012 from http://www.mdi.edu.

[16] Cohen, A. D. (1996). Second language learning and use strategies: Clarifying and issues. Retrieved November 2012 from http://www.carla.umn.edu.

[17] Cohen, A. D., \& Macaro, E. (2007). LLS and the future: resolving the issues. Language learner strategies (pp.274-284). Oxford: Oxford University Press.

[18] Daly, J. A. (1978). Writing apprehension and writing competency. The Journal of Educational Research, 72(1), 10-14. Retrieved October 2012 from http:// www.jstore.org.

[19] Daly, J.A., \& Miller, M. D. (1975). The empirical development of an instrument to measure writing apprehension. Research in the Teaching of English, 9(3), 242-249. Retrieved October 2012 from http://www.jstore.org.

[20] Daly, J.A., \& Wilson, D. A. (1983). Writing apprehension, self-esteem and personality. Research in the Teaching of English, 17(2), 327-341. Retrieved October 2012 from http://www.jstore.org.

[21] Dujisik, D. (2008). The effect of prewriting strategy training guided by computer-based procedural facilitation on ESL students' strategy use, writing quantity and writing quality (Doctoral dissertation). Retrieved February 2013 from http://www.scholarcommons.usf.edu/etd/221.

[22] Ehrman, M.E., \& Oxford, R.L. (1995). Cognition plus: Correlates of language learning success. Modern Language Journal, 79 , 67-89. doi:10.2307/329394. http://dx.doi.org/10.2307/329394.

[23] Erkan, D. Y., \& Saban, A. I. (2010). Writing performance relative to writing apprehension, self-efficacy in writing and attitudes toward writing: A correlational study in Turkish tertiary level EFL. Asian EFL Journal, 12(5), 164-192.

[24] Faigley, L., Daly, J. A., \& Witte, S. P. (1981).The role of writing apprehension in writing performance and competence. Retrieved November 2012 from http://www. eric.ed.gov.

[25] Fox, R. F. (1980). Treatment of writing apprehension and its effect on composition. Research in the Teaching of English, 14(1), 39-49. Retrieved November 2012 from http://www. eric.ed.gov.

[26] Goldstein, A. A., \& Carr, P. G. (1996). Can students benefit from process writing? Retrieved October2012 from http://www.eric.ed.gov.

[27] Hassan, B. A. (2001). The relationship of writing apprehension and self-esteem to the writing quality and quantity of EFL university students. Retrieved October 2012 from http://www. eric.ed.gov. 
[28] Hettich, R. (1994). Writing apprehension: A critique (Doctoral dissertation). Available from ProQuest Dissertation and Theses database.

[29] Holmes, V. K., \& Moulton, M. R. (2003). Behind the picture: Apprehension in the L2 writing process. TESL Reporter, 36(2), $27-40$.

[30] Huwari, I.F., \& Abd Aziz, N. H. (2011). Writing apprehension in English among Jordanian postgraduate students at university UTARA Malaysia. Academic Research International, 1(2), 190-198.

[31] Ibnian, S. K. (2011). Brainstorming and essay writing in EFL class. Theory and Practice in Language Studies, 1(3), $263-272$.

[32] Kroll, B. (2001). Consideration for teaching an ESL/EFL writing course. In M. Celce-Murcia (Eds.), Teaching English as a second or foreign language (pp.219-232). United State of America: Heinle and Heinle.

[33] Lee, S.Y. (2005). Facilitating and inhibiting factors in English as a foreign language writing performance: A model testing with structural equation modeling. Language Learning, 55(2), 335-374. doi:10.1111/j.0023-8333.2005.00306.x. http://dx.doi.org/10.1111/j.0023- 8333.2005.00306.x.

[34] Li, L. Y. (2007). Exploring the use of focused free writing in developing academic writing. Journal of University Teaching and Learning, 4 (1), 40-53.

[35] MacIntyer, P. D., Noels, K. A., \& Clement, R. (1997). Biases in self-rating of second language proficiency: The role of language anxiety. Language Learning, 47,265-287. doi: 10.1111/0023-8333.81997008. http://dx.doi.org/10.1111/00238333.81997008.

[36] Marshall, L. L., \& Varnon, A. W. (2009). Writing apprehension among accounting seniors. The Accounting Educators Journal, $19,45-65$

[37] Masny, D., \& Foxall, J. (1992). Writing apprehension in L2. Retrieved October 2012 from http://www. eric.ed.gov.

[38] Negari, G.M. (2011). A study on strategy instruction and EFL learners' writing skill. International Journal of English Linguistics, 1(2), 299-307. doi: 10.5539/ijel.v1n2p299. http://dx.doi.org/10.5539/ijel.v1n2p299.

[39] Ojima, M. (2006). Concept mapping as pre-task planning: A case study of three Japanese ESL writers. System, 34,566-585. doi:10.1016/j.system.2006.08.003. http://dx.doi.org/10.1016/j.system.2006.08.003.

[40] Oxford, R.L. (2002). Language learning strategies in a nutshell: Update and ESL suggestion. In J. C. Richards \& W.A. Renandya (Eds.), Methodology in Language teaching: An anthology of current practice (pp.124-132). Cambridge: Cambridge University Press.

[41] Ozturk, H., \& Cecen, S. (2007). The effect of portfolio keeping on writing anxiety of EFL students. Journal of Language and Linguistic Studies, 3(2), 218-236.

[42] Piovesan, M. C. (2007). The importance of free writing in teaching of English as a foreign language: A case study in Brazilian classroom (Master's thesis). Retrieved March 2013 from http://www.busca.unisul.br.

[43] Pishghadam, R., \& Ghanizadeh, A. (2006). On the impact of concept mapping as a prewriting activity on EFL learners' writing ability. IJAL, 9(2), 1-26.

[44] Rankin-Brown, M. S. (2006). Addressing writing apprehension in adults English language learners. Retrieved October 2012 from http://www. CA TESOL.org.

[45] Rao, Z. (2007). Training in brainstorming and developing writing skills. ELT Journal, 62(2), 100-106.doi: 10.1093/et1/ccmooz. http://dx.doi.org/10.1093/elt/ccm002.

[46] Reeves, L. L. (1997). Minimizing writing apprehension in the learner-centered classroom. The English Journal, 86(6), 38-45. Retrieved October 2012 from http://www.jstore.org.

[47] Salem, M. S. (2007). The effect of journal writing on writing performance, writing apprehension and attitudes of Egyptian English majors (Unpublished doctoral dissertation).The Pennsylvania State University, USA.

[48] Seow, A. (2002). The writing process and process writing. In J.C. Richards \& W.R. Renandya (Eds.), Methodology in language teaching: An anthology of Current practice (pp.315-320).Cambridge: Cambridge University press.

[49] Schweiker-Marra, K.E., \& Marra, W.T. (2000). Investigating the effect of prewriting activities on writing performance and anxiety of at-risk students. Reading Psychology, 21(2), 99-114.

[50] Song, M. (1997).The effect of dialogue journal writing on writing quality, reading comprehension and writing apprehension of EFL college students. Retrieved October 2012 from http://www.eric.ed.gov.

[51] Stern, C. (1991). Writing portfolios: A resource for teaching and assessment. Retrieved March 2013 from http://www.eric.ed.gov.

[52] Talebinezhad, M.R., \& Negari, G. M. (2007). The effect of explicit teaching of concept mapping in expository writing on EFL students' self-regulation. Pazhuhesh-e Zabanha-ye Khareji, 42, 85-108.

[53] Teichman, M.,\&Poris, M. (1989). Initial effects of word processing on writing quality and writing anxiety of freshman writers. Computers and the Humanities, 23(2), 93-103. Retrieved November 2012 from http://www.jstore.org.

[54] Tsui, A. B.M. (1996). Reticence and anxiety in second language learning. In K.M. Bailey \& D. Nunan (Eds.). Voices from the language classroom (pp.145-168). Cambridge: Cambridge University Press. Retrieved November 2012 from http://www.googlebook.com.

[55] Weigle, S.C. (2002). Assessing writing. Cambridge: Cambridge University Press.

[56] Wu, K. (2010). The relationship between language learners' anxiety and learning strategy in the CLT classrooms. International Education Studies, 3(1), 174-191.

Fatemeh Mohseniasl holds M.A. in TEFL from Islamic Azad University, Science and Research Branch, Tehran, Iran. Her areas of interest are learning strategies, affective factors in language learning and task-based language learning and teaching. She has taught English language in language schools and institutes and designed many tasks as supplementary materials for EFL learners. 